А.С. Могілатенко ${ }^{1}$, Д.М. Обідін ${ }^{2}$, О.П. Кондратенко ${ }^{3}$, В.М. Руденко ${ }^{2}$

${ }^{1}$ Військова частина А2183

${ }^{2}$ Кіровоградська льотна академія Національного авіаційного університету, Кропивницький

${ }^{3}$ Національна академія Національної гвардї України, Харків

\title{
ЗАБЕЗПЕЧЕННЯ РАДІОЛОКАЦІЙНОЮ ІНФОРМАЦІЄЮ РЕГІОНАЛЬНИХ ЦЕНТРІВ УПРАВЛІННЯ ПОВІТРЯНИМ РУХОМ
}

\begin{abstract}
Необхідність практичного вирішення завдання забезпечення регіонального центру повітряного руху радіолокаційною інформачією з необхідною повнотою і точністю та недостатня розвиненість теоретичної бази для ї̈ вирішення, зумовлюють актуальність наукової задачі розробки методу формування та видачі повідомлень про повітряні об'єкти від джерел радіолокаиійної інформаиії на регіональний центр управління повітряним рухом, адаптивного до змін продуктивності джерел радіолокаційної інформації $і$ пропускної здатності каналів передачі даних.
\end{abstract}

Ключові слова: аналіз, обробка, управління, інформація.

\section{Вступ та аналіз завдання}

Аналіз змісту процесу забезпечення радіолокаційною інформацією регіональних центрів управління повітряним рухом. Необхідною умовою вирішення задач управління на центрах управління повітряним рухом (ЦУПР) $є$ наявність радіолокаційної інформації (РЛІ) про повітряні об'єкти (ПО). Забезпечення радіолокаційною інформацією центрів управління повітряним рухом $є$ однією 3 функцій АСУ центрів управління повітряним рухом i являє собою сукупність взаємопов'язаних заходів по виявленню, збору, обробці, аналізу і видачі даних про повітряні об'єкти від джерел радіолокаційної інформації на центри управління повітряним рухом.

Під радіолокаційною інформацією про повітряні об'єкти в АСУ розуміють набір відомостей у вигляді формалізованих повідомлень про повітряні об'єкти, здобутих в ході радіолокаційної розвідки засобами активної і пасивної локації. Повідомлення про повітряні об'єкти складається з інформаційних елементів, які являють собою блоки даних в двійковому вигляді зі смисловим змістом, визначеним керівними документами: номер, місце розташування та час виявлення повітряних об'єктів; ознака розпізнавання державної приналежності; висота, склад, тип повітряних об'єктів; ознаки маневру по курсу, висоті і швидкості; ознаки застосування перешкод та ін. Повідомлення про повітряні об'єкти формуються і видаються джерелами РЛІ.

Можна виділити ряд топологічних особливостей підсистеми забезпечення РЛІ ЦУПР:

1. Підсистема забезпечення радіолокаційною інформацією регіонального центра управління повітряним рухом має складну структуру і інформація про ПО від джерел радіолокаційної інформації може надходити на регіональний центр управління повітряним рухом через кілька ланок управління.
2. Основними напрямами видачі радіолокаційної інформації є напрямки по вертикалі управління, тобто між підлеглими і вище стоячими ЦУПР. Разом 3 тим, наявність інформаційних зв'язків між ЦУПР одного рівня ієрархії в АСУ регіонального ЦУПР дозволяє організувати видачу РЛІ по обхідних маршрутах для підвищення живучості.

3. Наявність територіально рознесених джерел i споживачів РЛІ в АСУ регіонального ЦУПР обумовлює необхідність використання протяжних каналів передачі даних.

Перераховані особливості підсистеми забезпечення РЛІ регіонального ЦУПР визначають порядок вирішення задач цією підсистемою. До таких завдань відносяться: радіолокаційне спостереження за повітряним простором, збір, обробка та аналіз РЛІ, формування і видача повідомлень про ПО споживачам. Проведемо аналіз цих задач. Радіолокаційне спостереження в районі відповідальності ЦУПР і на підступах до нього засноване на певному порядку розміщення радіолокаційних засобів для створення суцільного радіолокаційного поля для своєчасного виявлення, упізнавання, розпізнавання і безперервного супроводу ПО. Особливості вирішення завдань процесу забезпечення радіолокаційною інформацією ЦУПР обумовлені принципами радіолокаційного спостереження: циклічний принцип огляду повітряного простору радіолокаційними засобами [1] визначає дискретний характер поновлення, обробки і видачі РЛІ; принцип перекриття зон виявлення РЛС для забезпечення надійного радіолокаційного спостереження призводить до дублювання радіолокаційної інформації, що вимагає усунення надмірності даних про ПО [2]; принципи радіолокації обумовлюють наявність помилок вимірювання координат ПО, що вимагає обліку точності радіолокаційної інформації при їі обробці [1].

3 урахуванням перерахованих особливостей вирішується задача збору РЛІ, яка складається в 
зосередженому і цілеспрямованому відборі необхідних даних про ПО на відповідних ЦУПР. При цьому здійснюється управління процесом збору, що складається у виборі джерел і регулюванні потоків РЛІ, виходячи з поставлених задач, умов обстановки, складу даних, які видаються цими джерелами. Під потоком РЛІ розуміють рух даних в каналі передачі даних у вигляді повідомлень про ПО з певною швидкістю, що називається щільністю потоку [2].

Особлива увага при зборі РЛІ звертається на перевантаження в ланках управління АСУ. Перевантаження являють собою ситуації, коли вхідний потік РЛІ не може бути повністю оброблений на ЦУПР і виданий споживачам зі встановленою дискретністю, тобто встановленим інтервалом часу між сусідніми повідомленнями про одне ПО. Це може бути викликано обмеженою продуктивністю АСУ та недостатньою пропускною спроможністю каналів передачі даних з причин їх радіоелектронного придушення, а також збільшення щільності потоку повідомлень про ПО. При цьому пропускна здатність визначає максимально можливу швидкість передачі даних по каналу, а продуктивність джерела РЛІ визначає кількість інформації про ПО, що видається в одиницю часу і може бути розрахована за формулою:

$$
\mathrm{G}=\frac{\mathrm{n} \cdot \mathrm{L}}{\mathrm{T}}=\mathrm{n} \cdot\left(\sum_{\mathrm{i}=1}^{\mathrm{k}} \mathrm{l}_{\mathrm{i}}+\mathrm{s}\right) / \mathrm{T},
$$

де G - продуктивність джерела РЛІ, біт/с; n - кількість ПО, за якими видаються повідомлення від джерела РЛІ; L - розмір повідомлення про ПО, біт; Т - період поновлення інформації про ПО, с; k кількість інформаційних елементів в повідомленні

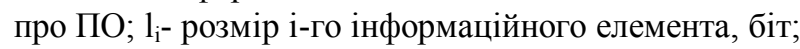
s - кількість службової інформації і розрядів, що не використовуються, біт.

Пропускна спроможність може бути визначена за формулою Шеннона [3]:

$$
\mathrm{C}=\mathrm{F} \cdot \log _{2}\left(1+\mathrm{P}_{\mathrm{c}} / \mathrm{P}_{\mathrm{W}}\right),
$$

де C - пропускна здатність каналу передачі даних, біт / c; F - ширина смуги пропускання каналу, Гц; $\mathrm{P}_{\mathrm{c}}$, $\mathrm{P}_{\text {ш }}$ - потужність сигналу і потужність шуму, Вт.

Пропускна здатність у формулі (2) визначає лише теоретично досяжне максимальне значення швидкості передачі даних. Тому в подальшому під пропускною спроможністю каналу будемо розуміти максимальну реалізовану швидкість передачі даних при заданій ймовірності помилки біта і позначати символом С. Разом $з$ тим, залежність (2) дозволяе визначити шляхи підвищення максимально реалізованої швидкості передачі даних в каналі.

Таким чином, причини перевантажень в ланках збору РЛІ можуть привести до перевищення продуктивності джерел РЛІ над пропускної спроможності каналів передачі даних. При такій неузгодженості між продуктивністю джерел і пропускною спроможністю каналів передачі даних, що забезпечуються
ЦУПР будуть отримувати РЛІ не в повному обсязі, що впливає на якість рішення задач обробки та аналізу РЛІ на цих ЦУПР.

Обробка РЛІ включає перевірку достовірності здобутих відомостей, формування трас польоту цілей, ототожнення і зіставлення інформації від декількох джерел. При цьому важлива точність РЛІ [4], яка характеризує розбіжності між фактичними i відображеними значеннями координат ПО. Як показник точності використовують середньоквадратичну помилку координат (с.к.п.) ПО:

$$
\sigma_{\mathrm{xy}}=\sqrt{\frac{1}{\mathrm{n}} \cdot \sum_{\mathrm{i}=1}^{\mathrm{n}} \delta_{\mathrm{i}}^{2}},
$$

де $\delta_{\mathrm{i}}$ - відстань між істинним і і-м виміряним положенням ПО.

Після обробки РЛІ на ЦУПР здійснюють аналіз отриманої інформації, який включає критичне осмислення, логічне зіставлення і узагальнення наявних відомостей для підвищення їх достовірності і виявлення узагальненої інформації. Однією 3 найбільш важливих характеристик, що впливають на результати аналізу РЛІ, являється повнота забезпечення РЛІ.

Після обробки та аналізу зібраної РЛІ формуються повідомлення про ПО і здійснюється їх видача споживачам відповідно до встановленого порядку. Формування повідомлення про ПО полягає у визначенні складу інформаційних елементів і присвоєння їм певних значень. Безпосередньо видача і прийом повідомлень про ПО між ЦУПР в АСУ регіонального ЦУПР здійснюється за допомогою системи передачі даних (СПД), яка об'єднує апаратуру передачі даних (АПД) джерел і споживачів радіолокаційної інформації за допомогою каналів передачі даних. Використовувана в АСУ регіонального ЦУПР СПД базується на первинній мережі зв'язку, яка морально застаріла (тільки 30\% засобів зв'язку можна вважати сучасними) і має низьку структурну живучість. Таким чином, 3 проведеного аналізу змісту процесу забезпечення радіолокаційною інформацією регіональних ЦУПР можна виділити ряд його особливостей: різке зростання щільності інформаційного потоку повідомлень про ПО по каналах передачі даних; зменшення кількості стаціонарних ЦУПР, вузлів зв'язку та каналів передачі даних в результаті їх придушення; зниження пропускної здатності радіоканалів передачі даних або вихід їх з ладу в результаті РЕП; збільшення щільності потоку повідомлень про ПО на обхідних маршрутах за рахунок додаткової радіолокаційної інформації від взаємодіючих джерел; моральне старіння і низька структурна живучість первинної мережі зв'язку, на якій базується СПД в АСУ регіонального ЦУПР. Зазначені особливості можуть призвести до неузгодженості між продуктивністю джерел РЛІ і пропускною спроможністю каналів передачі даних. Для усунення такої неузгодженості між продуктивністю джерела РЛІ і пропускною спроможністю каналу передачі даних можна 
використовувати ряд методів, що застосовуються в АСУ регіональних ЦУПР і в сучасних СПД [3].

Аналіз існуючих методів узгодження продуктивності джерела радіолокаційної інформації 3 пропускною спроможністю каналу передачі даних. Проведемо аналіз методів узгодження продуктивності джерел РЛІ з пропускною спроможністю каналів передачі даних в існуючих АСУ регіонального ЦУПР.

$\boldsymbol{A C У}$ «Луч-1». Основними джерелами РЛІ в АСУ «Луч-1» $є$ КЗА «Межа», КЗА «Низина-Н». Ці КЗА володіють низькими можливостями по супроводу ПО і видачі РЛІ: 50 ПО з Т = 10 с. у КЗА «Межа» та 10 ПО з Т = 10 с. у КЗА «Низина-Н». Повідомлення про ПО в обох джерел мають фіксований розмір і склад інформаційних елементів.

У разі перевищення кількості ПО, діючих в зоні інформації над інформаційними можливостями КЗА, в АСУ «Луч-1» застосовується метод селекції ПО: ЦУПР приймає від регіонального ЦУПР розпорядження про зняття 3 супроводження зазначених ПО. Разом з тим, застосування методу селекції ПО може вносити спотворення в реальну картину повітряної обстановки, так як не всі ПО видаються споживачеві. Таким чином, селекція ПО для їх видачі знижує повноту забезпечення РЛІ споживача.

При виході з ладу каналів передачі даних через придушення джерела РЛІ в АСУ «Луч-1» переходять на запасні канали передачі даних. Разом $з$ тим, з огляду на інтенсивне придушення СПД, застосування запасних каналів передачі даних, що використовують той самий маршрут передачі даних, може виявитися практично неможливим.

$\boldsymbol{A C У}$ «Луч-2». Основні джерела РЛІ в АСУ регіонального ЦУПР «Луч-2»: КЗА «Межа-М», що забезпечує видачу 50 ПО з Т = 10 с, і КЗА «Низина-У», що забезпечує видачу 20 ПО з Т = 10 с. Для усунення неузгодженості продуктивності цих джерел РЛІ і пропускною здатністю каналів передачі даних впливають ті ж методи, що і в АСУ «Луч-1». При цьому, в КЗА "Нізіна-У" є можливість збільшити дискретність видачі повідомлень по ПО до 20 с. Однак дискретність поновлення РЛІ впливає на іï точність, так як за час інтервалу між сусідніми повідомленнями розташування ПО може істотно змінитися. Збільшення дискретності видачі координат призводить до збільшення розривів трас і навіть до скидання ПО з супроводу.

В якості додаткових джерел РЛІ в АСУ «Луч-2» використовуються взаємодіючі ЦУПР, оснащені КЗА «Протон-2» і КЗА «Алмаз-2». Суть методу групування полягає в об'єднанні кількох ПО, що потрапляють в заданий просторовий строб і відповідають додатковим умовам, в один згрупований ПО з координатами головного ПО, розміщеного в середині переднього фронту строба. При цьому РЛІ видається по груповому ПО із зазначенням строба групування і кількості згрупованих в ньому ПО. Розміри строба групування по фронту і глибині можуть змінюватися від $40 \times 40$ км. до $100 \times 200$ км. Всі джерела РЛІ в АСУ «Луч-3» видають повідомлення про ПО з фіксованим розміром і складом інформаційних елементів. У разі виходу 3 ладу каналів передачі даних джерела РЛІ переходять на запасні канали, однак така можливість обмежена інтенсивним вогневим придушенням СПД в сучасних умовах бойових дій.

АСУ «Луч-3». В якості джерел РЛІ в АСУ «Луч-3» можуть використовуватися ті ж основні джерела, що і в «Луч-2» а також ряд нових джерел 3 фіксованим розміром і складом повідомлень про ПО, які використовують спеціальні протоколи для узгодження продуктивності цих джерел 3 пропускною спроможністю каналів передачі даних. Так КЗА «Поле» видає на регіональний ЦУПР 1 раз за 20 с. кодограму про завантаження (кількості супроводжуваних ПО). Ця інформація аналізується на ЦУПР і при наближенні завантаження до максимального вирішується задача про розвантаження КЗА. ЦУПР розвантажуються видачею на них дозволів не супроводжувати зазначені ПО. Як зазначалося раніше, таке обмеження потоку повідомлень про ПО, що видаються, призводить до зменшення повноти забезпечення РЛІ споживача, що спотворює реальну картину повітряної обстановки. При виході з ладу каналів передачі даних джерела РЛІ переходять на запасні канали, що може бути не піддається реалізації через інтенсивне вогневе придушення СПД.

ACУ «Піраміда». В якості джерела РЛІ в АСУ «Піраміда» [5] можуть використовуватися ті ж джерела, що і в АСУ «Луч-3», а також ряд нових джерел: КЗА «Основа-1», з видачею РЛІ про 120 ПО за 10 с; КЗА «Протон-2М-1», 3 такими ж інформаційними здібностями як у «Протон-2»; КЗА «Універсал»; КЗА «Поляна-Д4», з видачею РЛІ про 80 ПО за 10 с.

АСУ «Піраміда»є подальшим розвитком АСУ «Луч-3» за рахунок модернізації різних ланок комплексів технічних засобів, програмного і математичного забезпечення. Принципи узгодження продуктивності джерел РЛІ з пропускною спроможністю каналів передачі даних в АСУ «Піраміда» аналогічні тим, що використовуються в АСУ «Луч-3», що також призводить до зниження повноти і точності забезпечення РЛІ споживачів.

$\boldsymbol{A C У}$ «Бор-1». АСУ регіонального ЦУПР республіки Білорусь створена на основі об'єднання локальних обчислювальних мереж (ЛОМ) окремих ЦУПР. Вона здатна здійснювати збір та відображення РЛІ, вибирати оптимальний варіант їх розподілу. Ця мережа передачі даних базується на використанні протоколу передачі даних 3 комутацією пакетів по стандарту Х.25. Отже, основним методом усунення неузгодженості продуктивності джерела РЛІ і пропускної здатності каналу передачі даних в АСУ «Бор-1» $є$ використання різних маршрутів передачі РЛІ, тобто маршрутизація. Разом з тим, використання маршрутизації при передачі РЛІ вимагає обліку завантаження обхідних маршрутів, так як передача по ним транзитної інформації великого обсягу може привести до перевантажень каналів пере- 
дачі даних. АСУ регіонального ЦУПР нового покоління «Бор-1» створена на основі об'єднання ЛОМ окремих ЦУПР з використанням технології взаємодії відкритих систем. Така технологія має на увазі незалежність використовуваних типів апаратури передачі даних (АПД) (модемів) і протоколів передачі інформації від конкретної реалізації КЗА ЦУПР. Це дозволяє використовувати різні методи стиснення даних. При цьому стиснення даних - представлення даних меншим числом бітів в порівнянні з початковим [2].

Відомі методи стиснення спрямовані на зниження надмірності, викликаної як нерівною апріорною ймовірністю значень інформаційних елементів в потоці даних, так і залежністю між значеннями послідовних інформаційних елементів. Ефективність методів стиснення оцінюють коефіцієнтом стиснення, який дорівнює відношенню початкового об'єму даних до об'єму стиснених даних. При цьому стиснення буває з втратами і без втрат. Втрати допустимі при стисненні (і відновленні) деяких специфічних видів даних, таких як відео- і аудіо інформації. Якщо відновлені дані збігаються з даними, які були до стиснення, то говорять про стиснення без втрат. Саме такого роду методи стиснення застосовуються при передачі інформації в СПД [5].

На сьогоднішній день існує безліч методів стиснення даних без втрат, що поділяються на кілька основних груп [5, 7]: методи кодування повторів; імовірнісні методи стиснення; арифметичні методи стиснення; словникові методи стиснення.

Принцип кодування повторів $є$ найбільш простим і застосовується в основному для стиснення графічних файлів. Потік РЛІ, що видається від джерела, не володіє властивостями повторюваності значень в послідовних інформаційних елементах, що обумовлено їх різнорідною семантичною інтерпретацією. Тому кодування повторів для стиснення РЛІ буде неефективним. В основі імовірнісного стиснення лежать ідеї методів ефективного кодування Шеннона-Фано і Хаффмена [6]. Разом $з$ тим, отримати розподіл ймовірностей значень інформаційних елементів в повідомленнях про ПО не вдається 3 огляду на те, що на випадковий характер їх зміни впливають причини нестохастичної природи.

При використанні арифметичного кодування рядок інформаційних елементів замінюється дійсним числом більше нуля і менше одиниці. Арифметичне кодування дозволяє забезпечити високий коефіцієнт стиснення в тих випадках, коли стискаються дані, де частота появи різних інформаційних елементів сильно варіюється $[5,6]$. Такі випадки не характерні для потоку РЛІ, і процедура арифметичного кодування може не забезпечити узгодження продуктивності джерела РЛІ з пропускною спроможністю каналу передачі даних.

В основі методу словників [5] лежить ідея заміни кодових послідовностей, що найбільш часто зустрічаються, в переданому потоці посиланнями на «зразки», що зберігаються в спеціально створюваній таблиці (словнику). Але повідомлення про ПО мають обмежений розмір, який визначається складом необхідних відомостей про ПО, що може не забезпечити узгодження продуктивності джерела РЛІ 3 пропускною спроможністю каналу передачі даних при використанні словникових методів стиснення.

$\boldsymbol{A C У} \boldsymbol{A C C S}$. Принципи організації забезпечення споживачів РЛІ в АСУ в Свропі «ACCS» відрізняються від використовуваних в раніше розглянутих АСУ ЦУПР. Застосування мережевих технологій побудови $\mathrm{ACУ} \mathrm{«ACCS»} \mathrm{дозволяе} \mathrm{організувати} \mathrm{ЦУПР} \mathrm{на} \mathrm{базі}$ локальних обчислювальних мереж різної топології. Взаємодія між цими ЦУПР здійснюється за рахунок їх об'єднання в глобальну мережу з декількома рівнями ієрархії. Для зменшення надмірності циркулюючої РЛІ в такий АСУ використовуються два підходи. Перший підхід спрямований на обмеження потоків РЛІ, що видається, між рівнями ієрархії за рахунок відбору релевантної інформації за напрямками видачі за допомогою спеціальних буферів. Другий підхід полягає в відборі споживачами тільки тієї інформації з потоку РЛІ, яка їм необхідна. У разі виникнення перевантажень каналів передачі даних в АCУ «АCCS» використовується маршрутизація повідомлень про ПО, що видаються, і стиснення даних. При цьому повідомлення про ПО стандартизовані за складом РЛІ і розміром - 320 біт. При виході з ладу каналів передачі даних джерела РЛІ в АCУ «ACCS» переходять на запасні канали передачі даних. Аналіз даних методів проведено в розглянутих вище АСУ ЦУПР. Розглянуті АСУ ЦУПР можна умовно розділити за часом їх створення на АСУ старого покоління і нового. АСУ старого покоління «Луч-1 $(2,3) » \mathrm{i}$ «Піраміда» були розроблені в 70...80-х роках, і особливістю їх є суворе обмеження на кількість і типи КЗА, що входять до складу АСУ, а також строго певні типи АПД і протоколи для обміну інформацією між конкретними КЗА. Тому АСУ регіонального ЦУПР старого покоління являє собою закриту розподілену систему, для якої додавання заздалегідь не передбачених елементів вимагає зміни апаратного або програмного забезпечення існуючих елементів цієї системи. Таким чином, існуючі методи узгодження продуктивності джерела РЛІ з пропускною спроможністю каналу передачі даних можна розділити на дві групи за принципом узгодження: методи, спрямовані на збільшення або відновлення пропускної здатності С - будемо називати їх канальними методами: виділення додаткових каналів передачі даних та використання запасних каналів; маршрутизація повідомлень про ПО; методи, спрямовані на зменшення продуктивності джерел РЛІ G - будемо називати їх інформаційними методами: групування (укрупнення) ПО; селекція (відбір) ПО для їх видачі; збільшення дискретності видачі РЛІ для всіх ПО; стиснення даних.

Разом 3 тим, застосування канальних методів, пов'язаних $з$ використанням додаткових або запасних каналів передачі даних може виявитися практи- 
чно неможливим, зважаючи на інтенсивне придушення СПД. Тому в подальших дослідженнях ці методи розглядатися не будуть.

Зі змісту методів групування, селекції і збільшення дискретності видачі РЛІ видно, що їх застосування вносить спотворення в реальну картину повітряної обстановки і призводить до зниження повноти і точності забезпечення РЛІ споживача.

Застосування існуючих методів стиснення даних для зменшення щільності потоку РЛІ на 33,3\% (що призведе до узгодження між продуктивністю джерела РЛІ, збільшеної на 50\%, і пропускною спроможністю каналу ПД) вимагатиме досягнення коефіцієнта стиснення $\mathrm{K}_{\mathrm{cr}}>1,5$, інакше їх застосування знижує повноту забезпечення РЛІ регіонального ЦУПР. При цьому необхідно оцінити можливість такого стиснення, так як потік РЛІ, як показано раніше, не володіє необхідними властивостями для прийнятного стиснення існуючими методами.

Таким чином, в зв'язку з зазначеними недоліками існуючих методів узгодження джерел РЛІ 3 пропускною спроможністю каналів передачі даних, необхідно провести оцінку достатньої повноти і точності забезпечення РЛІ регіонального ЦУПР і впливу методів збільшення дискретності видачі РЛІ, групування і селекції ПО, а також існуючих методів стиснення даних на зазначені характеристики якості забезпечення РЛІ регіонального ЦУПР.

\section{Результати досліджень}

Оцінка повноти і точності забезпечення радіолокаційної інформацісю регіонального центру управління повітряним рухом. Найвищі вимоги до якості РЛІ на регіональному ЦУПР пред'являються при іiі видачі на активні засоби. Тому визначимо достатню точність і повноту забезпечення РЛІ регіонального ЦУПР для видачі цілевказівки на ЦУПР.

Вимоги до точності забезпечення РЛІ. Від точності видачі РЛІ залежить ймовірність беспошукового виявлення цілевказівки ЦУПР:

$$
\mathrm{P}_{\text {ЦУ }}=\Phi\left(\frac{0,5 \cdot \mathrm{R}_{\text {Д }}}{\sigma_{\text {Д }}}\right) \cdot \Phi\left(\frac{0,5 \cdot \mathrm{R}_{\beta}}{\sigma_{\beta}}\right) \cdot \Phi\left(\frac{0.5 \cdot \mathrm{R}_{\varepsilon}}{\sigma_{\varepsilon}}\right),
$$

де $\Phi$ - функція Лапласа; $\mathrm{R}_{д}, \mathrm{R}_{\beta}, \mathrm{R}_{\varepsilon}$ - розміри простору по дальності, азимуту і куту місця, що проглядаються на індикаторах ЦУПР; $\sigma_{д}, \sigma_{\beta}, \sigma_{\varepsilon}$ - с.к.в. РЛІ по дальності, азимуту і куту місця.

Припускаючи, що помилки цілевказівки в основному визначаються помилками по азимуту і куту місця і вони однакові, з виразу (4) отримуємо:

$$
\sigma_{\beta}=\sigma_{\varepsilon}=\sqrt{\sigma_{\beta б и}^{2}+\sigma_{\beta \text { сир }}^{2}} \leq 0,5 \cdot \mathrm{R}_{\beta(\varepsilon)} / \Phi^{-1}\left(\sqrt{\mathrm{P}_{Ц \mathrm{y}}}\right),
$$

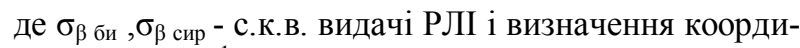
нат ЦУПР; $\Phi^{-1}$ - зворотня функція Лапласа.

Вимоги до повноти забезпечення РЛІ. Як показник повноти забезпечення РЛІ споживачів в АСУ ЦУПР використовують коефіцієнт проводки трас:

$$
\mathrm{K}_{\text {пр }}=\frac{\mathrm{N}_{\mathrm{B}}}{\mathrm{N}_{\mathrm{B}}+\mathrm{N}_{\mathrm{HB}}}=1-\frac{\mathrm{N}_{\mathrm{HB}}}{\mathrm{N}_{\mathrm{B}}+\mathrm{N}_{\mathrm{HB}}},
$$

де $\mathrm{N}_{\mathrm{B}}$ - кількість ПО, за якими видається РЛІ з необхідною якістю; $\mathrm{N}_{\mathrm{HB}}$ - кількість діючих ПО, за якими не видається РЛІ. Оцінимо відповідність отриманим вимогам до точності і повноти забезпечення РЛІ регіонального ЦУПР при використанні інформаційних методів узгодження пропускної спроможності каналів передачі даних з продуктивністю джерел РЛІ.

Оцінимо вплив збільшення дискретності видачі РЛІ на ії точність при забезпеченні РЛІ регіонального ЦУПР. Існуючі КЗА, що виступають в якості основних джерел РЛІ, забезпечують регіональне ЦУПР РЛІ 3 необхідною точністю $\sigma_{\mathrm{xy}} \leq 1000$ м при дискретності видачі РЛІ Т = 10с. Така дискретність визначається періодом огляду простору первинними джерелами РЛС. Тому одночасне збільшення дискретності видачі РЛІ споживачам по всім ПО еквівалентно видачі РЛІ від ЦУПР джерела не в кожному періоді їі поновлення від підлеглих джерел, а в кожному другому або третьому і т.д. періодах. Отже, мінімальне збільшення дискретності видачі РЛІ при такому підході складе 2Т. У цьому випадку, на регіональному ЦУПР необхідно буде екстраполювати координати ПО в пропущених циклах поновлення РЛІ для забезпечення безперервної видачі ЦУПР. При цьому с.к.в. екстрапольованих координат цілі при використанні моделі прямолінійного рівномірного руху ПО дорівнює

$$
\sigma_{\mathrm{e}(\mathrm{k}+1)}^{2}=\sigma_{\mathrm{p} л \mathrm{c}}^{2} \cdot 2 \cdot\left(2 \cdot \mathrm{k}^{2}+3 \cdot \mathrm{k}+1\right) /\left(\mathrm{k} \cdot\left(\mathrm{k}^{2}-1\right)\right),
$$

де $\mathrm{k}$ - кількість попередніх циклів поновлення РЛІ, що враховуються при екстраполяції на $\mathrm{k}+1$ цикл.

$\mathrm{B}$ існуючих АСУ прийнято обмежувати $\mathrm{k}=8$ через зниження чутливості супроводження до невеликим маневрів цілі, що забезпечує точність РЛІ при видачі $\sigma_{\mathrm{xy}}=0,6 \sigma_{\text {рлс. }}$ Тому, за умови безперервного супроводу ПО джерелом РЛІ, с.к.в. екстрапольованих координат ПО на регіональному ЦУПР в пропущених циклах видачі за формулою (7) складе $\sigma_{\mathrm{e}}=1,33 \sigma_{\text {ху }}$. Для випадку мінімального збільшення дискретності видачі РЛІ від джерела в 2 рази кожна друга відмітка про ПО при видачі іï з регіонального ЦУПР на ЦУПРД буде екстрапольованою. Тоді для визначення с.к.в. РЛІ слід провести перетворення виразу (3):

$$
\begin{gathered}
\sigma_{x y}=\sqrt{\frac{1}{n} \cdot \sum_{i=1}^{n} \delta_{i}^{2}}=\sqrt{\frac{1}{n}\left(\sum_{m=1}^{1} \delta_{m}^{2}+\sum_{k=1}^{n-1} \delta_{k}^{2}\right)}= \\
=\sqrt{\sigma_{m}^{2} / n+\sigma_{k}^{2} \cdot n /(n-1)},
\end{gathered}
$$

де $\mathrm{n}$ - кількість повідомлень про ПО, виданих 3 регіонального ЦУПР; $\delta_{\mathrm{m}}, \delta_{\mathrm{k}}-$ помилки координат для m-го ПО, отриманого на регіональному ЦУПР від джерела РЛІ, і для k-го екстрапольованого ПО; 1 - кількість повідомлень про ПО, що надійшли від джерела РЛІ на регіональний ЦУПР; n-1 - кількість 
екстрапольованих відміток ПО на регіональному ЦУПР.

Для випадку збільшеної дискретності видачі в 2 рази відповідно до виразу (8) отримаємо:

$$
\sigma_{\mathrm{xy} 2 \mathrm{~T}}=\sqrt{\left(\sigma_{\mathrm{e}}^{2}+\sigma_{\mathrm{xy}}^{2}\right) / 2}=1,18 \cdot \sigma_{\mathrm{xy}} \text {. }
$$

Тому, за умови $\delta_{\mathrm{xy}} \leq 1000$ м і безперервного супроводу ПО з прямолінійним і рівномірним рухом точність видачі РЛІ на регіональному ЦУПР $\sigma_{\text {ху2т }}$ може виявитися нижче необхідної. Разом 3 тим, реальний рух ПО не завжди відповідає обраній моделі, а радіолокаційне спостереження носить епізодичний характер, що ще більше знижує точність РЛІ. Результати моделювання показують, що при збільшенні дискретності видачі повідомлень про ПО в 2 рази точність видачі РЛІ не задовольняє встановленим параметрам. Оцінимо вплив методу групування ПО на точність видачі РЛІ.

Помилка положення пригрупованих ПО визначається відстанню від них до головної мети. Припускаючи рівномірний розподіл ПО в межах квадратного строба групування, можна оцінити с.к.п. координат пригрупованих ПО $\sigma_{x р}$ щодо центру строба:

$$
\sigma_{\mathrm{xp}}=\lambda /(2 \cdot \sqrt{3}), \sigma_{\mathrm{xyp}}=\sqrt{\sigma_{\mathrm{xp}}^{2}+\sigma_{\mathrm{yp}}^{2}}=0,41 \cdot \lambda,
$$

де $\lambda$ - розмір квадратного строба групування по фронту або в глибину, м. 3 урахуванням точності РЛІ по головному ПО визначимо с.к.в. координат

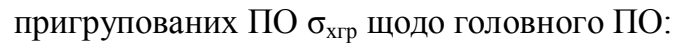

$$
\sigma_{\text {хугр }}=\sqrt{\sigma_{\text {хур }}^{2}+\sigma_{\text {ху }}^{2}} \text {. }
$$

При групуванні 33,3\% ПО для необхідного зменшення щільності потоку даних, РЛІ за цими ПО

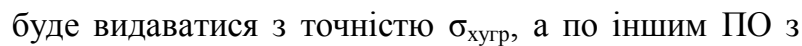

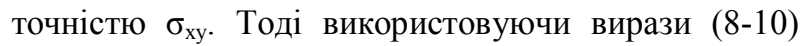
можна оцінити відповідність с.к.в. видачі РЛІ при використанні методу групування пропонованим вимогам до точності:

$$
\begin{gathered}
\hat{\sigma}_{\text {хугр }}=\sqrt{0,33 \sigma_{\text {хугр }}^{2}+0,67}= \\
=\sqrt{0,33\left(0,41^{2} \lambda^{2}+\sigma_{\text {ху }}^{2}\right)+0,67 \sigma_{\text {ху }}^{2}} \leq 1 \kappa
\end{gathered}
$$

Графічне рішення нерівності (11), представлене заштрихованою областю на рис. 1, дозволяє визначити область відповідності між розмірами строба групування і точністю РЛІ по незгрупованих ПО. Але обмеження відстаней між ПО та точність характеристик джерел не дозволяють забезпечити таку відповідність (рис. 1). Результати моделювання показують, що при групуванні 33,3\% ПО точність видачі РЛІ не задовольняє встановленим параметрам.

Оцінимо вплив методу селекції ПО на повноту забезпечення РЛІ регіонального ЦУПР. При використанні цього методу джерела РЛІ припиняють видачу повідомлень про деякі ПО, вказаних споживачем. У разі припинення видачі РЛІ по 33,3\% ПО для узгодження продуктивності джерела РЛІ $з$ пропускною спроможністю каналу передачі даних коефіцієнт проводки складе відповідно до виразу $1.8 \mathrm{~K}_{\text {пр }}=0,67$, що не задовольняє вимогам до повноти забезпечення радіолокаційною інформацією регіонального центру управління повітряним рухом.

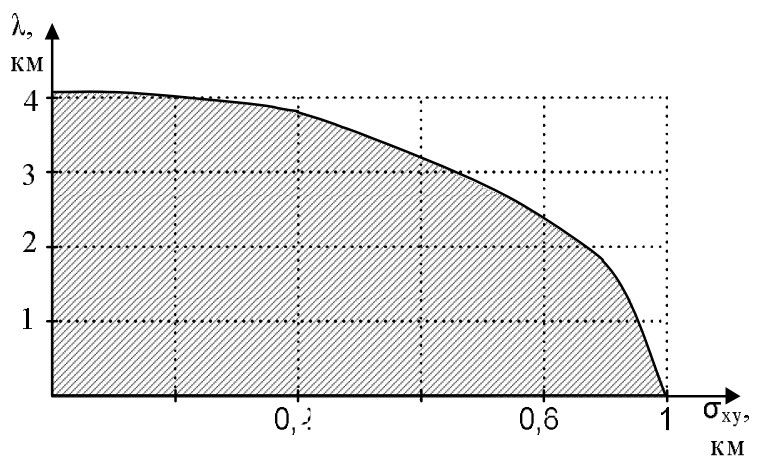

Рис. 1. Графік залежності розмірів строба групування $\lambda$ від точності РЛІ по незгрупованих ПО $\sigma_{\mathrm{xy}}$

Оцінимо коефіцієнти стиснення РЛІ при використанні міжнародних стандартів стиснення даних по протоколах MNP5, MNP7, V.42bis, V.44, які peaлізовані в сучасних модемах. Ці протоколи являють собою комбінації розглянутих в п.2 методів стиснення, а також набір правил узгодження параметрів стиснення даних.

Так протокол MNP5 реалізує кодування повтоpiв iз застосуванням коду Хаффмена. Протокол MNP7 використовує поліпшену форму кодування методом Хаффмена в поєднанні з марківським алгоритмом прогнозування. У протоколі V.42bis реалізований метод стиснення словникового типу, а в протоколі V.44 - його модифікація для використання в апаратурі супутникового зв'язку.

В результаті оцінки ефективності зазначених протоколів стиснення при передачі РЛІ отриманий графік залежності коефіцієнта стиснення $\mathrm{K}_{\text {ст }}$ від максимального розміру блоку даних L, що стискається, який можна встановлювати в сучасних модемах 3 наступного набору значень: 32, 64, 128, 256 байт (рис. 2).

Розміри повідомлень про повітряні об'єкти обмежені складом необхідних відомостей і не перевищують 32-х байт в АСУ центрів управління повітряним рухом старого покоління і 64-х байт в АСУ нового покоління. На рис. 2 показано, що потоку 32-байтових повідомлень відповідає $\mathrm{K}_{\text {ст }}=1,25$, а потоку 64-байтових повідомлень - $K_{\text {ст }}=1,3$. Тоді при необхідному

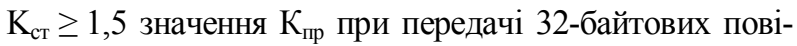
домлень складе $K_{\text {пр }}=1,25 / 1,5=0,83$, а 64-байтових повідомлень - $K_{\text {пр }}=1,3 / 1,5=0,87$, що не відповідає вимогам до повноти забезпечення радіолокаційною інформацією центрів управління повітряним рухом. 


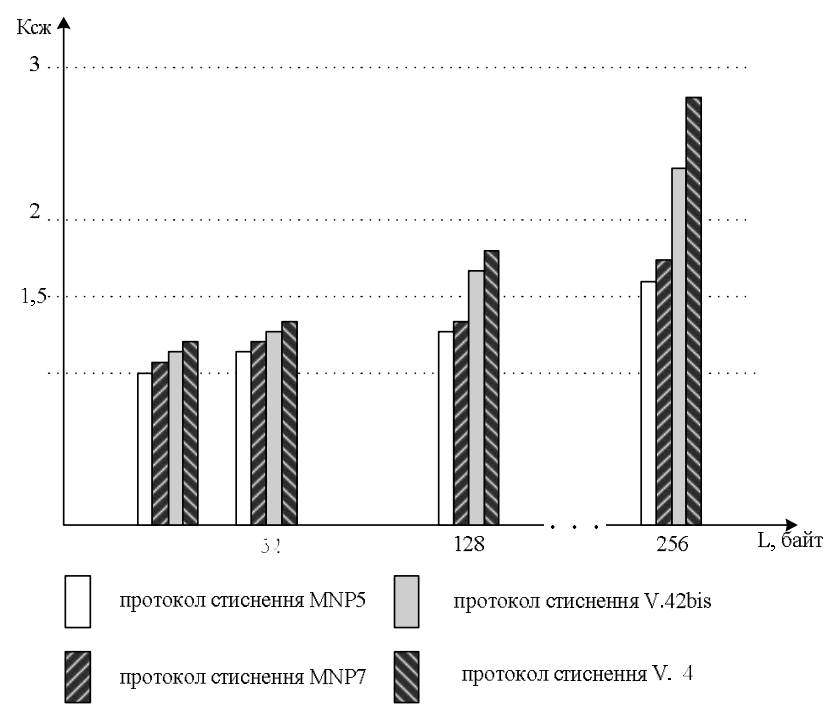

Рис. 2. Графік залежності коефіцієнта стиснення $\mathrm{K}_{\text {ст }}$ від максимального розміру блоку даних L, що стискається, для стандартних протоколів стиснення

\section{Висновки}

Існуючі інформаційні методи узгодження продуктивності джерел радіолокаційної інформації 3 пропускною спроможністю каналів передачі даних не забезпечують необхідну повноту і точність забезпечення радіолокаційною інформацією регіонального центру управління повітряним рухом. Причинами цього є фіксований розмір і склад інформаційних елементів в повідомленнях по всіх повітряних об'єктів, а також фіксована дискретність їх видачі. Жорстка структура повідомлення про повітряні об'єкти обумовлює надмірність при передачі даних, що не змінилися. Однакова дискретність видачі радіолокаційної інформації для всіх повітряних об'єктів призводить до надмірності радіолокаційної інформації по мало-швидкісним або неважливим у відношенні повітряним об'єктам і до неточної інформації по високошвидкісним або маневруючим повітряним об'єктам, а також по повітряним об'єктам, які в даний час мають найбільше значення.

Для вирішення протиріччя між достатньою і реалізованою повнотою і точністю забезпечення радіолокаційною інформацією центрів управління повітряним рухом доцільно використовувати нові принципи формування і видачі повідомлень про повітряні об'єкти, засновані на зміні складу і розміру інформаційних елементів в повідомленнях про повітряні об'єкти, а також дискретності видачі повідомлень по окремим повітряним об'єктам. Реалізація цих принципів можлива в перспективній АСУ центрів управління повітряним рухом, створюваної на основі об'єднання ЛОМ центрів управління повітряним рухом.

\section{Список літератури}

1. Турсунходжсаев Х.А. Теория цифровой обработки радиолокационной информации: Учебное пос. / Х.А. Турсунходжаев. - Х.: ВИРТА ПВО, 1989. - 125 с.

2. Словарь по кибернетике: Св. $2000 \mathrm{~cm}$. / Под ред. В.С. Михалевича. 2-е изд. - К.: Гл. ред. УСЭ им. М.Л. Бажана, 1989. - 751 c.

3. Столингс В. Компьютерные системы передачи данных / В. Столингс: Пер. с англ. - М.: Издательский дом "Вильямс", 2002. - 928 с.

4. Кузьмин С.3. Цифровая радиолокачия. Введение в теорию / С.3. Кузьмин. - К.: КВЩ, 2000. - 428 c.

5. Лагутенко О.И. Современные модемы / О.И. Лагутенко. - М.: Эко-Трендз, 2002. - 344 c.

6. Столингс В. Современные компьютерные сети / В. Столингс. - СПб.: Питер. 2003. - 783 c.

7. Метод формирования признаков информационной модели конфликтных ситуаиий для подсистем поддержки принятия решений в перспективных системах управления специального назначения / М.А. Павленко, Г.С. Степанов, М.В. Касьяненко, В.Н. Руденко // Збірник наукових праць Харківського національного університету Повітряних Сил. - Х.: ХНУПС, 2016. - Вип. 3. - C. 101-103.

Надійшла до редколегії 4.12.2017

Рецензент: д-р техн. наук, доц. М.А. Павленко, Харківський національний університет Повітряних Сил імені I. Кожедуба, Харків.

\title{
ОБЕСПЕЧЕНИЕ РАДИОЛОКАЦИОННОЙ ИНФОРМАЦИЕЙ РЕГИОНАЛЬНЫХ ЦЕНТРОВ УПРАВЛЕНИЯ ВОЗДУШНЫМ ДВИЖЕНИЕМ
}

\author{
А.С. Могилатенко, Д.Н. Обидин, А.П. Кондратенко, В.Н. Руденко
}

Необходимость практического решения задачи обеспечения регионального иентра воздушного движения радиолокационной информацией с требуемой полнотой и точностью и недостаточная развитость теоретической базы для ее решения, обуславливают актуальность научной задачи разработки метода формирования и выдачи сообщений о воздушных объектах от источников радиолокационной информации на региональный центр управления воздушным движением, адаптивного к изменениям производительности источников радиолокационной информации и пропускной способности каналов передачи данных.

Ключевые слова: анализ, обработка, управление, информация.

\section{THE PROVISION OF RADAR INFORMATION REGIONAL AIR TRAFFIC CONTROL CENTERS}

\author{
A.S. Mohilatenko, D.N. Obidin, O.P. Kondratenko, V.M. Rudenko
}

The need for a practical solution to the problem to ensure a regional center of air traffic radar information with the required completeness and accuracy, and insufficient development of the theoretical basis for its decision, cause the actual scientific task of developing a method of forming and issuing reports of aerial objects from radar data sources on a regional air traffic control center, adaptive to changes in the performance of radar data sources and bandwidth data channels.

Keywords: analysis, processing, management, information. 